\title{
PENGARUH MODEL PEMBELAJARAN RECIPROCAL TEACHING BERBANTUAN MEDIA AUDIO VISUALTERHADAP KOMPETENSI PENGETAHUAN IPA
}

\author{
I Gst. A. A. Aris Setianingsih \\ Jurusan Pendidikan Guru Sekolah Dasar, Universitas Pendidikan Ganesha \\ arissetyaningsih86@yahoo.co.id \\ DB. Kt. Ngr. Semara Putra \\ Jurusan Pendidikan Guru Sekolah Dasar, Universitas Pendidikan Ganesha \\ semaraputra@undiksha.ac.id \\ I Kt.Ardana \\ Jurusan Pendidikan Guru Sekolah Dasar, Universitas Pendidikan Ganesha \\ ardana_ketut55@yahoo.com
}

\begin{abstract}
Abstrak
Penelitian ini bertujuan untuk mengetahui pengaruh model pembelajaran reciprocal teaching berbantuan media audio visual terhadap kompetensi pengetahuan IPA siswa kelas IV SD Gugus Ir Soekarno Tahun Ajaran 2018/2019. Jenis penelitian ini adalah eksperimen semu dengan menggunakan rancangan non-equivalent control group design. Populasi dalam penelitian ini adalah seluruh siswa kelas IV SD Gugus Ir Soekarno yang berjumlah 269 siswa yang terdiri dari 8 kelas dari 4 sekolah. Sampel diambil dengan teknik random sampling. Kemudian dilakukan pengundian untuk menentukan kelompok eksperimen dan kelompok kontrol. Sehingga diperoleh sampel penelitian yaitu kelas IVB di SD Negeri 5 Pedungan sebagai kelompok eksperimen dengan jumlah 31 siswa dan kelas IVB di SD Negeri 2 Pedungan sebagai kelompok kontrol dengan jumlah 36 siswa. Data kompetensi pengetahuan IPA dikumpulkan dengan instrument objektif pilihan ganda biasa sebanyak 30 soal yang sudah divalidasi. Data yang diperoleh kemudian dianalisis menggunakan analisis uji-t polled varians. Hasil analisis data diperoleh $t_{\text {hitung }}=3,073>$ harga $t_{\text {tabel }}=2,000$ pada taraf signifikan $5 \%$ dengan $\mathrm{dk}=65$. Sehingga dapat dikatakan bahwa terdapat pengaruh model pembelajaran reciprocal teaching berbantuan media audio visual terhadap kompetensi pengetahuan IPA. Dilihat dari nilai rata-rata (mean) kompetensi pengetahuan IPA kelompok eksperimen $\overline{\mathrm{X}}=0,504$ dan pada kelompok kontrol $\overline{\mathrm{X}}=0,374$. Berdasarkan hasil penelitian tersebut dapat disimpulkan bahwa model pembelajaran reciprocal teaching berbantuan media audio visual berpengaruh terhadap kompetensi pengetahuan IPA siswa kelas IV SD Gugus Ir Soekarno Tahun Ajaran 2018/2019.
\end{abstract}

Kata Kunci:Reciprocal Teaching, Audio Visual, Kompetensi Pengetahuan IPA

\begin{abstract}
This study aims to determine the effect of reciprocal teaching learning models assisted by audio-visual media on science knowledge competencies of fourth grade students of Ir. Soekarno cluster Academic Year 2018/2019. This research was a quasi-experimental using a non-equivalent control group design. The populations were all fourth grade students of Elementary School Ir. Soekarno, there were 269 students consisting of 8 classes from 4 schools. The sample was taken by random sampling technique. In order to determine the experimental group and the control group, drawing was conducted. After that, the research sample obtained was class IVB in SD Negeri 5 Pedungan as an experimental group with a total of 31 students and class IVB in SD Negeri 2 Pedungan as a control group with a total of 36 students. Science knowledge competency data wascollected by the usual multiple choice objective instruments as many as 30 validated questions. The data obtained were then analyzed by using polled variance t-test analysis. The results of data analysis obtained thitung = $3.073>$ price $t$ table $=2,000$ at a significant level of $5 \%$ with $\mathrm{dk}=65$. So that it can be said that there is an influence of the reciprocal teaching learning model assisted by audio-visual media on science knowledge competencies. Judging from the average value (mean) of science competency in the experimental group $\bar{X}=0.504$ and in the control group $\bar{X}=0.374$. Based on the results of these studies it can be concluded that the reciprocal teaching learning model assisted by audio visual media influences the science competency of fourth grade students of SD Ir. Soekarno Academic Year 2018/2019.
\end{abstract}

Keywords: Reciprocal Teaching, Audio Visual, Science Knowledge Competency 


\section{Pendahuluan}

Dewasa ini pendidikan memegang peranan yang sangat penting dalam meningkatkan sumber daya manusia yang berkualitas. Hal ini mengarahkan pendidikan untuk menyiapkan lulusan yang mandiri artinya tujuan pendidikan tidak lagi semata-mata penyesuaian diri melainkan juga ditunjukkan pada peningkatan kemampuan dan kemauan masyarakat menuju mutu kehidupan yang lebih baik, mampu berfikir ke masa depan serta mempunyai keberanian untuk bertindak sesuai dengan apa yang dianggap benar.

Berdasarkan hal tersebut peran serta pemerintah, masyarakat sekitar dan orang tua sangat diperlukan dalam memberikan pendidikan untuk anak dalam mengembangkan potensi dalam mencapai kesuksesan. Sejalan dengan peningkatkan Sumber Daya Manusia yang lebih berkualitas, pendidikan juga terus berkembang ke arah yang lebih baik agar dapat menghasilkan lulusan terbaik.

Banyak tantangan yang dihadapi terutama pemerintah untuk meningkatkan kualitas pendidikan salah satunya yaitu dengan mengembangkan serta menyempurnakan kurikulum. Hal itu dikarenakan kurikulum sangat berperan penting sebagai pedoman dalam proses pembelajaran di sekolah. "Perubahan kurikulum tersebut didasari pada kesadaran bahwa perkembangan dan perubahan yang terjadi menuntut perlunya perbaikan sistem pendidikan nasional, termasuk penyempurnaan kurikulum untuk mewujudkan masyarakat yang mampu bersaing dan menyesuaikan diri dengan perubahan” (Kurniasih dan Sani, 2014:3).

Dalam rangka meningkatkan kualitas pendidikan, pemerintah Indonesia telah menetapkan kurikulum 2013 disetiap sekolah untuk mengembangkan potensi dan pembangunan karakter peserta didik.

Dalam proses pembelajaran kurikulum 2013 memberikan kesempatan pada peserta didik untuk menggali potensi yang telah dimiliki yang mencangkup pengembangan pada pengetahuan, sikap dan keterampilan dengan seimbang. Dalam menerapkan kurikulum 2013 disekolah, tentu dibantu oleh guru yang bertugas sebagai fasilitator untuk membantu siswa dalam membangun pengetahuan dengan berbagai sumber belajar. Namun sebaliknya, permasalahan yang sering terjadi dalam proses pembelajaran yaitu lemahnya proses pembelajaran yang diterapkan guru disekolah. Hal tersebut dilihat dari kurangnya guru dalam mengembangkan kemampuan berfikir siswa yang masih bergantung pada penjelasan yang disampaikan oleh guru.

Sehingga selama kegiatan pembelajaran di kelas berlangsung siswa hanya diarahkan pada kemampuan untuk menghafal suatu informasi tanpa dituntut untuk memahami informasi yang diperoleh untuk menghubungkannya dengan situasi dalam kehidupan sehari-hari. Dalam kurikulum 2013, hasil belajar siswa dapat dilihat dari pencapaian kompetensi inti yang diperoleh setelah mengalami proses belajar. Kompetensi merupakan sesuatu yang kompleks yang di dalamnya mengandung aspek (ranah) yaitu aspek pengetahuan, sikap dan keterampilan.

Dari berbagai muatan materi, hal tersebut juga menimpa salah satu muatan materi IPA. Dalam pelaksanaan kurikulum 2013, terdiri dari tema yang mengandung beberapa mata pelajaran, salah satu mata pelajaran yang terdapat dalam tema yaitu mata pelajaran IPA. Ilmu Pengetahuan Alam atau yang biasa disebut dengan IPA merupakan salah satu mata pelajaran yang terdapat pada jenjang sekolah dasar. Menurut Wisudawati dan Sulistyowati (2014:22) "IPA merupakan rumpun ilmu, memiliki karakteristik khusus yaitu mempelajari fenomena alam yang faktual (factual), baik berupa kenyataan (reality) atau kejadian (event) dan hubungan sebab akibatnya".

Pada dunia pendidikan pembelajaran bermuatan materi IPA memberikan kesempatan kepada siswa untuk mengembangkan rasa ingin tahu secara alamiah, sehingga membentuk kepribadian siswa dalam mengembangkan kompetensi pengetahuannya. Selain itu dengan mempelajari IPA siswa dapat mengetahui tentang makhluk hidup dan alam sekitar yang dekat dengan kehidupan siswa. Pentingnya penguasaan kompetensi pengetahuan IPA di sekolah tidak semata-mata untuk menyiapkan siswa untuk melanjutkan ke jenjang yang lebih tinggi, melainkan agar siswa mampu memecahkan permasalahan mengenai hal-hal yang dijumpai pada lingkungan sekitar berdasarkan pengetahuan yang diperoleh.

Dalam hal ini, perlu dilaksanakan inovasi dalam menyajikan materi pembelajaran agar dapat menarik perhatian siswa sehingga siswa termotivasi untuk belajar dan dapat membangun pengetahuannya sendiri. Pada kenyataannya, saat ini masih banyak siswa yang belum menguasai pembelajaran IPA karena dianggap sebagai mata pelajaran yang sulit dimengerti oleh siswa.

Berdasarkan hasil observasi yang dilaksanakan pada tanggal 19 dan 20 November 2018 dengan guru kelas IV di SD Gugus Ir. Soekarno. Saat proses pembelajaran berlangsung, kurangnya keaktifan siswa saat proses pembelajaran, selain itu kurangnya variasi guru saat menyampaikan materi pembelajaran kepada siswa, sehingga kegiatan pembelajaran masih berpusat pada guru. Kurangnya penggunaan media pada saat kegiatan belajar membuat siswa hanya membayangkan hal-hal yang disampaikan oleh guru tanpa mengetahui maksud yang disampaikan oleh guru.

Berdasarkan permasalahan tersebut dipandang perlu adanya inovasi dalam proses pembelajaran yaitu pembelajaran yang mengutamakan penguasaan kompetensi, berpusat pada siswa, dan dapat meningkatkan partisipasi siswa dalam mengikuti kegiatan pembelajaran. Salah satu inovasi yang dapat diterapkan dalam proses pembelajaran adalah model pembelajaran reciprocal teaching. 
"Reciprocal teaching adalah model pembelajaran berupa mengajarkan materi kepada teman" (Shoimin, 2014:153). Esensi dari model pembelajaran ini adalah siswa berperan sebagai guru untuk menyampaikan materi kepada teman-temannya. Guru hanya bertugas sebagai fasilitator dan pembimbing yang melakukan scaffolding. Menurut Shoimin (2014:153) "scaffolding adalah bimbingan yang diberikan oleh orang yang lebih tahu kepada orang yang kurang tahu atau belum tahu”. Model pembelajaran reciprocal teaching mengandung empat strategi yaitu pengajuan pertanyaan (question generating) yaitu siswa diberi kesempatan untuk membuat pertanyaan terkait materi yang sedang dibahas, klarifikasi (clarifying) yaitu siswa diberi kesempatan untuk membuat pertanyaan terkait materi yang sedang dibahas, prediksi (predicting) yaitu siswa melakukan hipotesis atau perkiraan mengenai konsep apa yang akan didiskusikan selanjutnya oleh penyaji, dan perangkuman (summarizing) yaitu siswa diberikan kesempatan untuk mengidentifikasi dan mengintegrasikan informasiinformasi yang terkandung dalam materi.

Pada penelitian ini, untuk menarik perhatian siswa dan memotivasi siswa dalam mengikuti pembelajaran maka dalam penerapan model pembelajaran ini dibantu dengan penggunaan media audio visual. Menurut Arsyad (2017:3) "media adalah perantara atau pengantar pesan dari pengirim kepada penerima pesan". Dalam hal ini dengan menggunakan media pada saat kegiatan pembelajaran diharapkan dapat meningkatkan minat siswa dalam mengikuti kegiatan pembelajaran. Salah satunya yaitu media audio visual.

"Media audio visual merupakan media yang dapat menampilkan unsur gambar dan suara secara bersamaan pada saat mengomunikasikan pesan atau informasi" (Wati, 2016:5). Media audio visual dapat mengungkapkan objek dan peristiwa seperti keadaan yang sesungguhnya. Dalam penerapan model pembelajaran reciprocal teaching dikombinasikan dengan penggunaan media audio visual yang dapat memotivasi dan dapat meningkatkan minat siswa dalam mengikuti kegiatan pembelajaran.

Dalam kurikulum 2013, hasil belajar siswa dapat dilihat dari pencapaian kompetensi inti yang diperoleh setelah mengalami proses belajar. Kompetensi merupakan sesuatu yang kompleks, yang di dalamnya mengandung aspek (ranah) yaitu aspek pengetahuan, sikap dan keterampilan. Kompetensi pengetahuan dapat dinyatakan sebagai kompetensi pada ranah kognitif yang mampu mengukur tingkat penguasaan atau pencapaian siswa dalam aspek pengetahuan yang meliputi enam aspek. Taksonomi Bloom ranah kognitif yang telah disempurnakan oleh Lorin Anderson Krathwohl yaitu mengingat, memahami, menerapkan, menganalisis, mengevaluasi dan mencipta. (Kosasih, 2014).

Berdasarkan paparan tersebut dapat disimpulkan, penguasaan kompetensi pengetahuan merupakan kemampuan pengetahuan yang dicapai siswa setelah memperoleh pengalaman belajarnya. Dalam hal ini, kompetensi pengetahuan merupakan kemampuan siswa terhadap penguasaan materi pembelajaran IPA dari kemampuan berpikir atau kognitif.

Menurut Susanto (2015:167) "IPA adalah usaha manusia dalam memahami alam semesta melalui pengamatan yang tepat pada sasaran". Dalam pembelajaran IPA siswa dapat memiliki rasa ingin tahu untuk menggali berbagai pengetahuan baru dan dapat mengaplikasikannya dalam kehidupan sehari-hari. Pada saat ini dalam proses belajar di sekolah terlihat bahwa siswa belajar karena suatu kewajiban bukan karena suatu kebutuhan. Oleh karena itu diperlukan suatu proses pembelajaran IPA yang mampu diaplikasikan oleh peserta didik dalam kehidupan nyata.

Berdasarkan pemaparan diatas dapat disimpulkan kompetensi pengetahuan IPA merupakan kemampuan pengetahuan yang memiliki karakteristik alam berupa peristiwa yang terjadi secara faktual dan aktual serta hubungan sebab akibat yang terjadi didalamnya berdasarkan hasil yang dicapai siswa setelah memperoleh pengalaman belajar.

Model pembelajaran yaitu suatu kerangka konseptual untuk mengorganisasikan pengalaman belajar yang berfungsi dalam penyusunan pencapaian pembelajaran yang akan digunakan sebagai pedoman bagi pengajar dalam kegiatan pembelajaran untuk mencapai tujuan pembelajaran tertentu.

Menurut Fathurrohman (2015:195). "model pembelajaran adalah kerangka konseptual yang digunakan sebagai pedoman dalam melakukan kegiatan pembelajaran" Pada saat ini model pembelajaran telah banyak dikembangkan. Setiap model pembelajaran akan membantu merancang pembelajaran, sehingga setiap siswa bisa mencapai tujuan pembelajaran.

Pada saat ini model pembelajaran telah banyak dikembangkan. Setiap model pembelajaran akan membantu merancang pembelajaran, sehingga setiap siswa bisa mencapai tujuan pembelajaran. Terdapat banyak model pembelajaran yang telah dikembangkan oleh guru yang dapat memberikan kemudahan bagi siswa untuk memahami dan menguasai pelajaran tertentu. Pengembangan model pembelajaran sangat tergantung dari karakteristik mata pelajaran ataupun materi yang akan diberikan kepada siswa, sehingga tidak ada model pembelajaran tertentu yang diyakini sebagai model pembelajaran yang paling baik.

Model pembelajaran reciprocal teaching menekankan pada siswa untuk bekerja dalam suatu kelompok yang telah dibentuk sehingga setiap anggotanya dapat berkomunikasi dan dapat saling bertukar pikiran. Model pembelajaran reciprocal teaching memiliki langkah-langkah pembelajaran yaitu (1) guru membentuk siswa ke dalam beberapa kelompok secara heterogen, (2) Siswa ditugaskan untuk membuat pertanyaan mengenai hal-hal yang belum dipahami berdasarkan video yang telah diamati (question generating), (3) Guru menugaskan 
perwakilan siswa dari masing-masing kelompok untuk menyajikan hasil diskusi kelompok dengan memberi peran bahwa siswa sebagai "guru", (4) Siswa diberikan kesempatan bertanya kepada temannya yang berperan sebagai guru mengenai materi yang belum dipahami (Clarifying), (5) Guru mengarahkan siswa untuk mengerjakan soal yang memuat soal pengembangan dari materi yang akan dibahas pada pertemuan selanjutnya (Predicting), (6) Siswa ditugaskan untuk menyimpulkan materi yang telah dipelajari (Summarizing).

Model reciprocal teaching memiliki keunggulan yaitu memberikan kesempatan kepada siswa untuk berperan sebagai guru, sehingga dapat melatih siswa berbicara di depan kelas dan dapat menjelaskan kembali materi yang telah dipelajari kepada siswa lainnya. Model reciprocal teaching memotivasi siswa untuk mengikuti pembelajaran.

Dalam suatu proses pembelajaran untuk meningkatkan pemahaman siswa mengenai materi yang dibelajarkan perlu adanya alat dan sumber belajar yang mampu membangun pengetahuan siswa kearah yang lebih luas. Oleh karena itu diperlukan pemanfaatan media sebagai salah satu alat penunjang proses pembelajaran. Menurut Arsyad (2017:3) "media adalah alat yang menyampaikan atau mengantarkan pesan-pesan pembelajaran" Sedangkan Wati (2016:2) "media merupakan segala bentuk alat yang dipergunakan dalam penyaluran atau penyampaian informasi". "Media pembelajaran merupakan komponen sumber belajar yang mengandung materi instruksional di lingkungan siswa yang memotivasi siswa untuk belajar" (Wati, 2016:3).

Berdasarkan uraian tersebut dapat didefinisikan media pembelajaran merupakan salah satu sarana yang dapat membantu guru dalam menyampaikan informasi kepada siswa sehingga siswa termotivasi dalam mengikuti pembelajaran.

Media audio visual merupakan media yang menampilkan unsur suara dan gambar. Penggabungan kedua unsur ini membuat media audio visual memiliki kemampuan yang lebih baik dan menarik, terutama dalam proses pembelajaran. "Media audio visual merupakan media yang dapat menampilkan unsur gambar dan suara secara terpadu pada saat mengomunikasikan pesan atau informasi" (Wati, 2016:44). Perpaduan antara gambar dan suara pada media audio visual akan membentuk sebuah karakter yang sama dengan objek aslinya.

Alat-alat yang termasuk dalam kategori media audio visual adalah televisi, video atau VCD, dan film. Perangkat yang diperlukan dalam penyampaian materi dengan menggunakan media audio visual adalah mesin proyektor film, tape recorder, dan proyektor visual yang lebar.

Berdasarkan uraian tersebut dapat disimpulkan bahwa model pembelajaran reciprocal teaching berbantuan media audio visual yaitu kegiatan pembelajaran yang menekankan pada kegiatan siswa untuk menyampaikan materi kepada teman, serta dengan pemanfaatan media audio visual saat proses pembelajaran, siswa dapat lebih termotivasi dalam mengikuti kegiatan pembelajaran dan siswa dapat berperan aktif dalam proses pembelajaran. Sedangkan guru berperan sebagai pembimbing dan fasilitator.

Adapun tujuan dalam penelitian ini adalah untuk mengetahui pengaruh model pembelajaran reciprocal teaching berbantuan media audio visual terhadap kompetensi pengetahuan IPA siswa kelas IV SD Gugus Ir. Soekarno Tahun Ajaran 2018/2019.

Metode

Penelitian ini merupakan jenis penelitian kuantitatif dengan desain experimen semu (quasi experiment design) dengan menggunakan rancangan kelompok non-equivalen control group design. Tempat pelaksanaan penelitian ini adalah di SD Gugus Ir Soekarno Tahun Ajaran 2018/2019 pada semester II (genap). Populasi dalam penelitian ini adalah seluruh siswa kelas IV SD Gugus Ir Soekarno Tahun Ajaran 2018/2019 yang terdiri dari 8 kelas dari 4 sekolah dasar dengan jumlah populasi yaitu 269 siswa.

Teknik pengambilan sampel pada penelitian ini adalah random sampling yang diacak adalah kelas, sehingga setiap kelas mendapatkan peluang yang sama untuk menjadi sampel penelitian. Untuk menentukan sampel, cara yang digunakan adalah dengan cara pengundian. Setelah itu, dua kelas hasil pengundian diberikan pretest, kemudian nilai atau skor dari hasil pretest yang dilakukan tersebut digunakan untuk penyetaraan kelas sampel.

Setelah terdapat kelas yang diketahui setara secara akademik, maka dilakukan pengundian untuk menentukan kelas eksperimen dan kelas kontrol, maka undian yang muncul yaitu kelas IV B SD Negeri 5 Pedungan dengan jumlah 31 siswa sebagai kelompok eksperimen dan kelas IV B SD Negeri 2 Pedungan sebagai kelompok kontrol.

Metode yang digunakan dalam dalam pengumpulan data penelitian ini adalah metode tes. Jenis tes kompetensi pengetahuan IPA yang digunakan dalam penelitian ini adalah tes pilihan ganda biasa.

Data kompetensi pengetahuan IPA siswa kelas IV SD Gugus Ir Soekarno dikerjakan dengan bantuan Microsoft office excel 2007 . Untuk analisis uji prasyarat mengunakan analisis uji normalitas menggunakan Kolmogorov-smirnov, uji homogenitas varians menggunakan uji F, dan uji hipotesis menggunakan uji-t dengan rumus polled varians. 


\section{Hasil dan Pembahasan}

Berdasarkan hasil perhitungan diperoleh nilai rata-rata gain score ternormalisasi kompetensi pengetahuan IPA siswa kelas IV untuk kelas eksperimen yang dibelajarkan dengan menggunakan model pembelajaran reciprocal teaching berbantuan media audio visual yaitu 0,504 dengan standar deviasi 0,1558 dan varians 0,0243 , sedangkan nilai rata-rata (mean) dari gain skor kelompok kontrol yang dibelajarkan dengan pembelajaran konvensional yaitu 0,374 dengan standar deviasi 0,1857 dan varians 0,0345 .

Dari hasil data perhitungan yang diperoleh, menunjukkan bahwa gain skor kompetensi pengetahuan IPA siswa kelompok eksperimen yang dibelajarkan dengan model pembelajaran reciprocal teaching berbantuan media audio visual memiliki rata-rata lebih tinggi dibandingkan dengan kelompok kontrol yang dibelajarkan dengan pembelajaran konvensional. Sebelum dilakukan uju hipotesis terlebih dahulu dilakukan uji prasyarat analisis yaitu uji normalitas sebaran data dan uji homogenitas varians.

Uji normalitas dilakukan untuk mengetahui apakah sebaran data skor kompetensi pengetahuan IPA siswa kelompok eksperimen dan kelompok kontrol berdistribusi normal atau tidak. Uji normalitas sebaran data dalam penelitian ini menggunakan uji Kolmogorov-Smirnov, dengan kriteria pengujian pada taraf signifikansi 5\% yaitu apabila nilai $|\mathrm{FT}-\mathrm{FS}|$ terbesar $\leq$ nilai tabel Kolmogorov-Smirnov, maka data berdistribusi normal.

Berdasarkan hasil tabel kerja uji normalitas sebaran data kelompok eksperimen diperoleh angka penguji normalitas, yaitu 0,1034 dengan taraf signifikansi $5 \%(\alpha=0,05)$ dan $\mathrm{N}=31$, sehingga diperoleh harga nilai tabel Kolmogorov-Smirnov, yaitu 0,238. Hal tersebut menunjukkan bahwa $\left|\mathrm{F}_{\mathrm{T}}-\mathrm{F}_{\mathrm{S}}\right|=0,1034<$ harga nilai tabel Kolmogorov-Smirnov $=0,238$, maka sebaran data dari data gain score ternormalisasi kompetensi pengetahuan IPA Kelas eksperimen berdistribusi normal.

Berdasarkan hasil tabel kerja uji normalitas sebaran data kelompok kontrol diperoleh angka penguji normalitas, yaitu 0,2122 , dengan taraf signifikansi $5 \%(\alpha=0,05)$ dan $\mathrm{N}=36$, sehingga diperoleh harga nilai tabel Kolmogorov-Smirnov, yaitu 0,221. Hal tersebut menunjukkan bahwa $\left|\mathrm{F}_{\mathrm{T}}-\mathrm{F}_{\mathrm{S}}\right|=0,2122<$ harga nilai tabel Kolmogorov-Smirnov $=0,221$, maka sebaran data dari data gain score ternormalisasi kompetensi pengetahuan IPA Kelas kontrol berdistribusi normal.

Tabel 1. Rekapitulasi Hasil Uji Normalitas Kelompok Eksperimen dan Kelompok Kontrol

\begin{tabular}{cccccc}
\hline No & Kelompok Sampel & $\begin{array}{c}\text { Jumlah } \\
\text { Sampel }\end{array}$ & $\begin{array}{c}\text { Nilai Maksimum } \\
\left|\mathbf{F}_{\mathbf{T}}-\mathbf{F}_{\mathbf{S}}\right|\end{array}$ & $\begin{array}{c}\text { Nilai Tabel Kolmogorov } \\
\text { Smirnov }\end{array}$ & Kesimpulan \\
\hline 1 & Eksperimen & 31 & 0,1034 & 0,238 & Normal \\
2 & Kontrol & 36 & 0,2122 & 0,221 & Normal \\
\hline
\end{tabular}

Uji homogenitas varians dilakukan berdasarkan data kompetensi pengetahuan IPA yang meliputi data kelompok eksperimen dan data kelompok kontrol. Uji homogenitas varian untuk kedua kelompok digunakan uji F. Kriteria pengujian jika $F_{\text {hitung }}<$ harga $F_{\text {tabel }}$ maka sampel homogen. Pengujian dilakukan pada taraf signifikan $5 \%$ dengan derajat kebebasan untuk pembilang $\mathrm{n} 1-1$ dan derajat kebebasan untuk penyebut $\mathrm{n} 2-1$.

Berdasarkan hasil perhitungan diperoleh harga $\mathrm{F}_{\text {hitung }}=1,42$, dengan taraf signifikansi $5 \%(\alpha=0,05)$ dengan dk untuk pembilang yaitu 36-1= $35 \mathrm{dan}$ dk untuk penyebut yaitu $31-1=30$, sehingga diperoleh harga $\mathrm{F}_{\text {tabel }}=1,79$. Oleh karena harga $\mathrm{F}_{\text {hitung }}=1,42<$ harga $\mathrm{F}_{\text {tabel }}=1,79$, maka data gain score ternormalisasi kompetensi pengetahuan IPA kelas eksperimen serta kelas kontrol dinyatakan memiliki varians yang homogen.

Tabel 2. Rekapitulasi Hasil Uji Homogenitas

\begin{tabular}{clccccc}
\hline No & Sampel & Varians & $\mathbf{d k}$ & $\mathbf{F}_{\text {hitung }}$ & $\mathbf{F}_{\text {tabel }}$ & Simpulan \\
\hline 1 & Kelas Eksperimen & 0,0243 & 30 & 1,42 & \multirow{2}{*}{1,79} & \multirow{2}{*}{ Homogen } \\
2 & Kelas Kontrol & 0,0345 & 35 & & \\
\hline
\end{tabular}

Adapun hipotesis penelitian yang diuji adalah tidak terdapat perbedaan yang signifikan kompetensi pengetahuan IPA antara kelompok siswa yang dibelajarkan melalui model pembelajaran Reciprocal Teaching berbantuan media Audio Visual dengan kelompok siswa yang dibelajarkan melalui pembelajaran konvensional pada siswa kelas IV SD Gugus Ir Soekarno tahun pelajaran 2018/2019. Uji hipotesis dilakukan dengan

menggunakan analisis uji-t. Adapun kriteria pengujiannya adalah apabila $t_{\text {hitung }} \leq t_{\text {tabel }}$, maka

$\mathrm{H}_{0}$ diterima.Sebaliknya apabilat $\mathrm{t}_{\text {hitung }} \geq \mathrm{t}_{\text {tabel }}$, maka $\mathrm{H}_{0}$ ditolak. Dengan $\mathrm{db} \mathrm{n}_{1}+\mathrm{n}_{2}-2$ dan taraf signifikansi 5\% $(\alpha=0,05)$. 
Tabel 3. Rekapitulasi Hasil Analisis Uji-t Kelompok Sampel Penelitian

\begin{tabular}{clccccccc}
\hline No & Sampel & $\mathbf{N}$ & $\mathbf{d k}$ & $\overline{\mathbf{X}}$ & $\mathbf{S}^{2}$ & $\mathbf{t}_{\text {hitung }}$ & $\mathbf{t}_{\text {tabel }}$ & Simpulan \\
\hline 1 & Kelas Eksperimen & 31 & & 0,504 & 0,0243 & \multirow{2}{*}{3,073} & \multirow{2}{*}{2,000} & \multirow{2}{*}{$\mathrm{H}_{0}$ ditolak } \\
2 & Kelas Kontrol & 36 & 65 & 0,374 & 0,0345 & & & \\
\hline
\end{tabular}

Berdasarkan hasil perhitungan diperoleh harga $t_{\text {hitung }}=3,073$, harga ini kemudian dibandingkan dengan harga $t_{\text {tabel }}$ pada taraf signifikansi $5 \%(\alpha=0,05)$ dengan $\mathrm{dk}=\mathrm{n} 1+\mathrm{n} 2-2=31+36-2=65$ sehingga diperoleh harga $\mathrm{t}_{\text {tabel }}=2,000$. Oleh karena harga $\mathrm{t}_{\text {hitung }}=3,073>$ harga $\mathrm{t}_{\text {tabel }}=2,000$, maka $\mathrm{H}_{0}$ ditolak dan Ha diterima. Hal ini berarti terdapat perbedaan yang signifikan kompetensi pengetahuan IPA antara kelompok siswa yang dibelajarkan melalui model pembelajaran Reciprocal Teaching berbantuan media Audio Visual dengan kelompok siswa yang dibelajarkan melalui pembelajaran konvensional pada siswa kelas IV SD Gugus Ir Soekarno tahun pelajaran 2018/2019.

Dilihat dari rata-rata kompetensi pengetahuan IPA siswa kelompok eksperimen lebih besar dari rata-rata

kompetensi pengetahuan IPA siswa kelompok kontrol $(\bar{X}=0,504>\bar{X}=0,374)$. Sehingga dapat disimpulkan bahwa penerapan model pembelajaran Reciprocal Teaching berbantuan media audio visual berpengaruh terhadap kompetensi pengetahuan IPA siswa kelas IV SD Gugus Ir. Soekarno tahun ajaran 2018/2019.

Berdasarkan hasil temuan tersebut, perolehan data kompetensi pengetahuan IPA pada kedua kelompok dapat diketahui bahwa kedua kelompok yang awalnya memiliki kemampuan setara, lalu setelah diberikan perlakuan yang berbeda, kompetensi pengetahuan IPA siswa pada kelompok eksperimen lebih baik dibandingkan dengan kompetensi pengetahuan IPA siswa pada kelompok kontrol. Dilihat dari rata-rata kompetensi pengetahuan IPA siswa yang dibelajarkan dengan model pembelajaran reciprocal teaching berbantuan media audio visual lebih tinggi dibandingkan dengan rata-rata siswa yang dibelajarkan dengan pembelajaran konvensional.

Perbedaan kompetensi pengetahuan IPA pada kelompok eksperimen dan kelompok kontrol disebabkan karena perlakuan berupa model reciprocal teaching berbantuan media audio visual yang diberikan kepada kelompok eksperimen berjalan dengan optimal. Hal tersebut dikarenakan model pembelajaran reciprocal teaching berbantuan media audio visual melatih siswa untuk berbicara di depan kelas yaitu dengan berperan sebagai "guru" untuk membelajarkan teman-temannya, sedangkan guru lebih berperan sebagai fasilitator dan pembimbing dalam pembelajaran, yaitu meluruskan atau memberi penjelasan mengenai materi yang tidak dapat dipecahkan secara mandiri oleh siswa. Selain itu dengan bantuan media audio visual dapat meningkatkan motivasi siswa dalam proses pembelajaran dan memudahkan siswa dalam memahami materi yang disampaikan.

Selain itu pembelajaran akan menjadi tidak kaku karena guru menggunakan variasi saat pembelajaran sehingga kegiatan pembelajaran tidak monoton. Model pembelajaran reciprocal teaching ini mampu melatih siswa untuk bekerja sama dan menghargai teman yang berbicara di depan kelas, secara tidak langsung melatih siswa untuk berinteraksi secara baik dengan teman sekelasnya yang dipadukan dengan media audio visual yang memudahkan siswa menerima pembelajaran dan mampu meningkatkan motivasinya dalam proses pembelajaran di kelas.

\section{Simpulan}

Berdasarkan hasil penelitian yang telah dilaksanakan, dapat disimpulkan bahwa model pembelajaran Reciprocal Teaching berbantuan media audio visual berpengaruh terhadap kompetensi pengetahuan IPA siswa kelas IV SD Gugus Ir. Soekarno tahun ajaran 2018/2019. Hal ini terbukti dari analisis data menggunakan uji-t diperoleh diperoleh harga $t_{\text {hitung }}=3,073$, harga ini kemudian dibandingkan dengan $t_{\text {tabel }}$ pada taraf signifikan 5\% $(\alpha=0,05)$ dengan $\mathrm{dk}(31+36-2=65)$. Sehingga diperoleh harga $t_{\text {tabel }}=2,000$. Oleh karena harga $t_{\text {hitung }}=3,073>$ harga $\mathrm{t}_{\text {tabel }}=2,000$, maka $\mathrm{H}_{0}$ ditolak. Selain itu nilai rata-rata pada kedua kelompok yaitu kelompok eksperimen $\overline{\mathrm{X}}=0,504$ dan pada kelompok kontrol $\overline{\mathrm{X}}=0,374$.

Adapun saran yang dapat disampaikan setelah melaksanakan dan memperoleh hasil dari penelitian yaitu sebagai berikut. Bagi guru dengan diadakan penelitian ini diharapkan guru dapat menambah wawasannya mengenai inovasi pembelajaran sehingga dapat menerapkan dan mengembangkan pembelajaran di kelas secara lebih inovatif dan bervariasi agar dapat memberikan dampak positif dalam meningkatkan kompetensi pengetahuan siswa. Bagi sekolah dengan diadakan penelitian ini, pihak sekolah diharapkan mampu untuk memanfaatkan hasil penelitian sebagai acuan dalam mengembangkan variasi dalam proses pembelajaran di kelas dengan menyediakan fasilitas untuk menunjang pembelajaran agar siswa semakin termotivasi untuk belajar dan memanfaatkan fasilitas yang disediakan untuk mengoptimalkan kompetensi pengetahuan siswa. Peneliti lain diharapkan hasil penelitian ini dapat digunakan sebagai salah satu referensi untuk melaksanakan penelitian selanjutnya atau sebagai acuan dalam mengembangkan penelitian yang relevan. 


\section{Daftar Pustaka}

Agung, A. A. G. 2014. Buku Ajar Metodelogi Penelitian Pendidikan. Malang: Aditya Media Publishing. Arsyad, Azhar. 2017. Media Pembelajaran. Jakarta: PT Raja Grafindo Persada.

Arikunto, Suharsimi. 2015. Dasar-Dasar Evaluasi Pendidikan. Jakarta: Bumi Aksara.

Cahyono, Tri.2015. Statistik Uji Normalitas. Purwokerto: Yayasan Sanitarian Banyumas.

Dantes. 2017. Desain Eksperimen dan Analisis Data. Depok: PT Rajagrafindo Persada.

Dantes. 2012. Metode Penelitian. Yogyakarta: C.V ANDI OFFSET.

Darmadi.2017. Pengembangan Model dan Metode Pembelajaran dalam Dinamika Belajar Siswa. Yogyakarta: Deepublish. Dewi, Ni. Putu. Karmina. Ratna. 2017. "Pengaruh Model Pembelajaran Snowball Throwing Berbantuan Media Audio Visual Terhadap Penguasaan Kompetensi Pengetahun IPA". Jurnal Education of Technology, Volume $1, \quad$ No $\quad 1, \quad$ (hlm $\quad-$ ). $\quad$ Tersedia pada https://ejournal.undiksha.ac.id/index.php/JET/article/view/12504/7824 (diakses tanggal 16 November 2018)

Fatthurrohman. 2015. Paradigma Pembelajaran Kurikulum 2013 Strategi Alternatif Pembelajaran di Era Global. Yogyakarta: Kalimedia

Kosasih. 2014. Strategi dan Pembelajaran Implementasi Kurikulum 2013. Bandung: Yrama Widya.

Kurniasih, Imas dan Berlin Sani. 2014. Sukses Mengimplementasikan Kurikulum 2013. Kata Pena.

Mahayanti, Gst. A. Md. 2013. "Pengaruh Model Pembelajaran Reciprocal Teaching Berbantuan Mind Mapping Terhadap Pemahaman Jonsep IPA Siswa kelas IV Semester II SD No 1 Baktiseraga”. Jurnal Pendidikan Mimbar PGSD Universitas Pendidikan Ganesha Jurusan PGSD, Volume 1, Nomor 1, (hlm. 4). Tersedia pada https://ejournal.undiksha.ac.id/index.php/JJPGSD/article/view/1281/1142 (diakses tanggal 12 November 2018).

Samatowa, Usman. 2016. Pembelajaran IPA di Sekolah Dasar. Jakarta: Indeks.

Sanjaya, Wina. 2013. Strategi Pembelajaran Berorientasi Standar Proses Pendidikan. Bandung: Kencana Prenadamedia Group.

Setyosari, Punaji. 2015. Metode Penelitian Pendidikan \& Pengembangan. Jakarta: Prenadamedia Group.

Shoimin, Aris. 2014. 68 Model Pembelajaran Inovatif dalam Kurikulum 2013. Yogyakarta: Ar-Ruzz Media.

Sugiyono. 2017. Metode Penelitian Pendidikan. Bandung: Alfabeta.

Sugiyono. 2017. Statistika Untuk Penelitian. Bandung: Alfabeta.

Susanto, Ahmad. 2015. Teori Belajar \& Pembelajaran di Sekolah Dasar. Jakarta: Kencana.

Suteni, Kd. (2013). "Pengaruh Model Pembelajaran Reciprocal Teaching Terhadap Hasil Belajar IPA Pada Siswa Kelas V SD Gugus 1 Kecamatan Buleleng”. Jurnal Pendidikan Mimbar PGSD Universitas Pendidikan Ganesha Jurusan PGSD, Volume 1, Nomor 1 (hlm. 3). Tersedia pada https://ejournal.undiksha.ac.id/index.php/JJPGSD/article/view/1357/1218 (diakses tanggal 12 November 2018).

Wati, Ega Rima. 2016. Ragam Media Pembelajaran. Kata Pena.

Wisudawati dan Sulistyowati. 2014. Metodologi Pembelajaran IPA. Jakarta: Bumi Aksara. 